\title{
Endogenous amino acid flow in the avian ileum: quantification using three techniques
}

\author{
V. Ravindran*†, L. I. Hew $\ddagger$, G. Ravindran $\dagger$ and W. L. Bryden§ \\ Department of Animal Science, The University of Sydney, Camden, NSW 2570, Australia
}

(Received 22 December 2003 - Revised 16 April 2004 - Accepted 21 April 2004)

\begin{abstract}
The aim of the present study was to compare the protein-free diet, guanidinated casein $(\mathrm{GuC})$ and enzyme hydrolysed casein (EHC) methods for the quantification of endogenous amino acid (AA) flow in the avian ileum. Growing broiler chickens (5 weeks old) were used. All three assay diets were based on dextrose, and in the GuC and EHC diets GuC or EHC were the sole source of N. Endogenous AA flows determined with the use of protein-free diet were considerably lower $(P<0.05)$ than those determined by the GuC and EHC methods. The total endogenous AA flows determined by the GuC and EHC methods were almost 3-fold greater $(P<0 \cdot 05)$ than those determined by the protein-free diet. The endogenous AA values obtained from GuC and EHC methods were similar $(P>0.05)$, except for the flow of arginine, which was lower $(P<0.05)$ in the EHC method. Glutamic acid, aspartic acid, threonine and glycine were the predominant endogenous AA present in digesta from the distal ileum. The contents of methionine, histidine and cystine were lower compared with other AA. The method of determination had no effect on the AA composition of endogenous protein, except for threonine, glutamic acid, lysine, arginine and cystine. The concentrations of threonine and arginine were lower $(P<0.05)$ and that of lysine was higher $(P<0.05)$ with the EHC method compared with the other two methods. The concentration of glutamic acid was greater $(P<0.05)$ and that of cystine was lower $(P<0.05)$ in the EHC and GuC methods compared with the protein-free diet method. The results showed that the ileal endogenous flows of $\mathrm{N}$ and AA are markedly enhanced by the presence of protein and peptides, above those determined following feeding of a proteinfree diet. It is concluded that the use of EHC and GuC methods enables the measurement of ileal endogenous losses in chickens under normal physiological conditions.
\end{abstract}

Ileal endogenous amino acid flow: Enzyme hydrolysed casein: Guanidinated casein: Protein-free diet: Chickens

Significant losses of endogenous amino acids (AA) occur during the process of digestion and absorption along the gastrointestinal tract. Correction for these inevitable losses is necessary for the estimation of true digestibility values of feed ingredients. A measure of these losses is also necessary for the determination of AA requirements by the factorial method. Endogenous proteins originate predominantly from various digestive secretions, mucoproteins and desquamated epithelial cells lining the gut. The endogenous flow of AA in poultry has traditionally been determined by the measurement of AA excretion in fasted birds or in birds fed a protein-free diet (Sibbald, 1987). These techniques, however, suffer from the limitation that starvation or the absence of protein may cause a reduction of digestive secretions and alter gut metabolism, resulting in an underestimation of endogenous AA flows. Several studies have conclusively demonstrated that the protein-free diet method leads to considerable underestimation of endogenous AA flow in single-stomached animals (Darragh et al. 1990; Butts et al. 1993; Siriwan et al. 1994).

Two new techniques, based on the feeding of guanidinated casein ( $\mathrm{GuC}$; Hagemeister \& Erbersdobler, 1985) or enzyme hydrolysed casein (EHC; Moughan et al. 1990), which distinguish between endogenous secretions and exogenous or dietary sources of AA under normal feeding conditions, are now available. Guanidination is the chemical process wherein the lysine moieties in dietary proteins are transformed to homoarginine (2-amino-6-guanidino-hexanoic acid) by reaction with $o$-methylisourea. Homoarginine is released from protein following digestion and absorbed in a manner similar to other AA, but is not used for body-protein synthesis and therefore does not reappear in endogenous secretions into the gut. After the homoarginine-labelled protein is fed, endogenous AA flows are determined by comparing the AA:homoarginine ratios in the diet and ileal digesta (Bryden et al. 1996). This approach has been applied to the measurement of

\footnotetext{
Abbreviations: AA, amino acids; AIA, acid-insoluble ash; EHC, enzyme hydrolysed casein; GuC, guanidinated casein.

* Corresponding author: Dr Velmurugu Ravindran, fax + 646350 5685, email V.Ravindran@massay.ac.nz

$\dagger$ Present address: Institute of Food, Nutrition and Human Health, Massey University, Palmerston North, New Zealand.

$\ddagger$ Present address: Chia Tai Co. Ltd, No. 1, FanHua Avenue, Economic \& Technology Development Area, Hefei, Anhui Province 230601, China.

$\S$ Present address: School of Animal Studies, University of Queensland, Gatton, QLD 4343, Australia.
} 
ileal endogenous AA losses in poultry (Angkanaporn et al. 1994; Siriwan et al. 1994). In the EHC method, the animal is fed a semipurified diet containing EHC, composed of free AA and peptides with a molecular mass $<10 \mathrm{kDa}$, as the sole source of protein. The ileal digesta is collected from the animal, and the endogenous protein (molecular mass $>10 \mathrm{kDa}$ ) is separated from unabsorbed free AA and peptides by centrifugation and ultrafiltration. This method has been used to measure ileal endogenous AA losses in pigs (Butts et al. 1991; Moughan et al. 1992; Leterme et al. 1996; Hodgkinson et al. 2000), but corresponding data in poultry are limited.

The objective of the present study was to compare the protein-free diet, GuC and EHC methods for the quantification of endogenous AA flow in the avian ileum. Growing broiler chickens ( 5 weeks old) were used in the experiment. No studies to date have compared the use of these three methods to determine the endogenous AA flows in chickens. It was hypothesised that the presence of dietary peptides or protein would stimulate the flows of endogenous AA in the gut of chickens.

\section{Materials and methods}

\section{Ethical considerations}

All experimental procedures were approved by the University of Sydney Animal Care and Ethics Committee and complied with the Australian Code of Practice for the Care and Use of Animals for Scientific Purposes.

\section{Guanidination of casein}

$\mathrm{GuC}(5 \mathrm{~kg})$ was prepared using the large-scale guanidination procedure described by Imbeah et al. (1996). Briefly, casein was slowly added to a $0.4 \mathrm{M}-O$-methylisourea solution, stirred well, and the $\mathrm{pH}$ adjusted to 10.5. After $24 \mathrm{~h}$ incubation in a cold room, the $\mathrm{pH}$ of the mixture was gradually reduced to 3.0 and it was allowed to stand for $3 \mathrm{~h}$ so that the protein precipitate could settle. The supernatant fractions were then siphoned off and the precipitated protein was washed three times with water at $\mathrm{pH} 3$. After the last wash, the excess water was removed from the $\mathrm{GuC}$ by squeezing through a cotton cloth. The material was then dried in a forced-draft oven at $35^{\circ} \mathrm{C}$ and ground through a hammer-mill. The extent of guanidination was calculated from the levels of lysine and homoarginine in $\mathrm{GuC}$ as determined by HPLC (Siriwan et al. 1994). The conversion efficiency of lysine to homoarginine in $\mathrm{GuC}$, based on molar ratios (Ravindran et al. 1996), was $98.5 \%$.

\section{Diets}

Four diets were formulated, including a basal diet, a protein-free diet and diets containing $\mathrm{GuC}$ or $\mathrm{EHC}$ as the sole source of protein (Table 1). The basal diet was similar to the EHC diet except that casein was used in place of EHC. Celite (Celite Corporation, Lompoc, CA, USA), a source of acid-insoluble ash (AIA), was added to all diets as an inert marker for the calculation of AA flows.
Table 1. Composition ( $\mathrm{g} / \mathrm{kg}$, air-dry basis) of the protein-free diet and diets containing enzyme hydrolysed casein $(\mathrm{EHC})$ and guanidinated casein (GuC)

\begin{tabular}{|c|c|c|c|c|}
\hline Ingredient & $\begin{array}{l}\text { Basal } \\
\text { diet }^{*}\end{array}$ & $\begin{array}{l}\text { Protein-free } \\
\text { diet }\end{array}$ & $\begin{array}{l}\text { EHC } \\
\text { diet }\end{array}$ & $\begin{array}{l}\text { GuC } \\
\text { diet }\end{array}$ \\
\hline $\begin{array}{l}\text { Dextrose } \\
\text { Casein }\end{array}$ & $\begin{array}{l}617 \cdot 0 \\
200 \cdot 0\end{array}$ & $819 \cdot 0$ & $617 \cdot 0$ & $642 \cdot 0$ \\
\hline $\begin{array}{l}\text { Casein } \\
\text { GC }\end{array}$ & - & - & - & $175 \cdot 0$ \\
\hline $\mathrm{EHC} \dagger$ & - & - & $200 \cdot 0$ & - \\
\hline Solkafloc & $35 \cdot 0$ & $35 \cdot 0$ & $35 \cdot 0$ & $35 \cdot 0$ \\
\hline Soyabean oil & $50 \cdot 0$ & $50 \cdot 0$ & $50 \cdot 0$ & $50 \cdot 0$ \\
\hline Celite $\neq$ & $20 \cdot 0$ & $20 \cdot 0$ & $20 \cdot 0$ & $20 \cdot 0$ \\
\hline $\mathrm{Ca}_{2} \mathrm{PO}_{4}$ & $19 \cdot 0$ & $19 \cdot 0$ & $19 \cdot 0$ & $19 \cdot 0$ \\
\hline Limestone & $13 \cdot 0$ & $13 \cdot 0$ & $13 \cdot 0$ & $13 \cdot 0$ \\
\hline $\mathrm{NaHCO}_{3}$ & $20 \cdot 0$ & $20 \cdot 0$ & $20 \cdot 0$ & $20 \cdot 0$ \\
\hline $\mathrm{K}_{2} \mathrm{HPO}_{4}$ & $12 \cdot 0$ & $12 \cdot 0$ & $12 \cdot 0$ & $12 \cdot 0$ \\
\hline $\mathrm{MgO}$ & $2 \cdot 0$ & - & $2 \cdot 0$ & $2 \cdot 0$ \\
\hline Premix§ & $7 \cdot 0$ & $7 \cdot 0$ & $7 \cdot 0$ & $7 \cdot 0$ \\
\hline Choline chloride & $3 \cdot 0$ & $3 \cdot 0$ & $3 \cdot 0$ & 3.0 \\
\hline $\mathrm{NaCl}$ & $2 \cdot 0$ & $2 \cdot 0$ & $2 \cdot 0$ & $2 \cdot 0$ \\
\hline
\end{tabular}

*The basal diet was fed to all birds for $4 \mathrm{~d}$ before the introduction of the experimental diets.

† Sigma Chemical Co., St Louis, MO, USA; molecular mass, <5000 Da. According to the manufacturer, the molecular mass profile was (\%): $1-$ $500 \mathrm{Da} 90,500-1000 \mathrm{Da} 9,1000-2500 \mathrm{Da},>2500 \mathrm{Da} 0$.

$\ddagger$ Added as a source of acid-insoluble ash marker (Celite Corporation, Lompoc, CA, USA).

$\S$ Provided (per kg diet): trans-retinol $4.6 \mathrm{mg}$, cholecalciferol $118 \mu \mathrm{g}$, DL- $\alpha-$ tocopheryl acetate $28 \mathrm{mg}$, menadione $2.8 \mathrm{mg}$, thiamin $2.1 \mathrm{mg}$, riboflavin $11.2 \mathrm{mg}$, pyridoxine $7 \mathrm{mg}$, cyanocobalamin $21 \mu \mathrm{g}$, biotin $140 \mu \mathrm{g}$, niacin $42 \mathrm{mg}$, calcium pantothenate $21 \mathrm{mg}$, folic acid $2.8 \mathrm{mg}, \mathrm{Mn} 105 \mathrm{mg}, \mathrm{Zn}$ $70 \mathrm{mg}$, Fe $28 \mathrm{mg}$, Cu $7 \mathrm{mg}$, I $1.4 \mathrm{mg}$, Co $420 \mu \mathrm{g}$, Se $140 \mu \mathrm{g}$, Mo $2.2 \mathrm{mg}$, choline chloride $420 \mathrm{mg}$, ethoxyquin $175 \mathrm{mg}$

$\mathrm{K}_{2} \mathrm{HPO}_{4}$ and $\mathrm{NaHCO}_{3}$ were used as cationic sources to maintain a dietary electrolyte balance of $250 \mathrm{mEq} / \mathrm{kg}$ diet.

\section{Birds}

Broiler chicks (Cobb; $1 \mathrm{~d}$ old) were obtained from a local hatchery and housed in thermostatically controlled starter batteries with raised wire-mesh floors in a room where temperature and ventilation were controlled. Room temperature was maintained at $32 \pm 1{ }^{\circ} \mathrm{C}$ during the first week and gradually reduced to $24^{\circ} \mathrm{C}$ by the end of the third week and to $21^{\circ} \mathrm{C}$ during the fifth week. The birds received commercial broiler starter crumbles $(230 \mathrm{~g}$ protein $/ \mathrm{kg}$ ) from days 1 to 20. The birds were transferred to battery cages on day 21 and fed a commercial broiler finisher diet $(200 \mathrm{~g}$ protein $/ \mathrm{kg})$ in mash form until used in the experiment. Feed and water were supplied ad libitum and the birds received continuous fluorescent lighting throughout the study.

On day 27 post-hatching, the birds were weighed and sixty birds (mean weight 1.53 (SD 0.08) kg) were assigned to twelve pens of five birds each. The allocation of birds was made using a computer program that was designed to minimise variation in initial weights between replicate pens. Each dietary treatment was then randomly assigned to three pens of birds. Following a fast of $12 \mathrm{~h}$ on day 27 , the basal diet was introduced and fed for the next $3 \mathrm{~d}$. The use of the casein-based basal diet enabled the birds to adjust to the change-over from the commercial mash diet to purified diets. This adjustment was necessary to maintain satisfactory feed intake levels when purified 
diets are introduced. The basal diet was withdrawn on the evening of day 33 and the three test diets were introduced on the morning of day 34 and offered for $4 \mathrm{~d}$.

\section{Digesta collection and processing}

On day 37, all birds were killed by an intracardial injection of diluted sodium pentabarbitone solution $(200 \mathrm{ml} / \mathrm{l} ; 50 \mathrm{mg} /$ $\mathrm{kg}$ body weight). The body cavity was exposed and the ileum (from Meckel's diverticulum to a point $40 \mathrm{~mm}$ proximal to the ileocaecal junction) was removed. The ileum was then divided into two and the contents of the lower half of the ileum were collected by gently flushing with distilled water into plastic containers. Samples from birds within a pen were pooled, frozen immediately after collection and subsequently freeze-dried. Diet and dried ileal digesta samples were ground to pass through a $0.5 \mathrm{~mm}$ sieve and stored in airtight containers at $-4^{\circ} \mathrm{C}$ for chemical analyses.

\section{Chemical analyses}

Ileal digesta from birds fed the protein-free diet and $\mathrm{GuC}$ diet were analysed for N, AA and AIA, and the three diets for AIA as described earlier.

In the case of digesta from birds fed the EHC diet, the following procedure was first employed to separate the endogenous protein fraction (Butts et al. 1993). The freeze-dried samples were re-suspended in deionised water and acidified to $\mathrm{pH} 3.5$ with $9 \mathrm{M}-\mathrm{H}_{2} \mathrm{SO}_{4}$. The samples were stored overnight at $4^{\circ} \mathrm{C}$ and then centrifuged at $1450 \mathrm{~g}$ for $45 \mathrm{~min}$ at $0^{\circ} \mathrm{C}$. Each supernatant fraction was decanted off and retained. The precipitate was washed with $10 \mathrm{ml}$ deionised water and centrifuged at $1450 \mathrm{~g}$ for $30 \mathrm{~min}$ at $0^{\circ} \mathrm{C}$. The second supernatant fraction was added to the first; the precipitate was stored at $-20^{\circ} \mathrm{C}$. The combined supernatant fractions were ultrafiltered using a Centriprep-10 ultrafiltering device (molecular mass cut-off filter $10 \mathrm{kDa}$; Amicon Inc., Beverly, MA, USA) according to the manufacturer's instructions. The precipitate from the centrifugation step was added to the retentate $(>10 \mathrm{kDa})$ from the ultrafiltration step, and the material was freezedried. This fraction was analysed for N, AA and AIA.

The $\mathrm{N}$ contents of the diet and ileal digesta samples were determined by the method of Sweeney (1989) using a FP$428 \mathrm{~N}$ determinator $\left(\right.$ LECO $^{\circledR}$ Corporation, St Joseph, MI, USA). AA concentrations were determined by HPLC as described by Siriwan et al. $(1993,1994)$ following postcolumn derivatisation with $o$-phthaldialdehyde (Sigma Chemical Co., St Louis, MO, USA). Cystine and methionine were analysed as cysteic acid and methionine sulfone by oxidation with performic acid for $16 \mathrm{~h}$ at $0^{\circ} \mathrm{C}$ and neutralisation with hydrobromic acid before hydrolysis (Moore, 1963). Tryptophan contents were determined following alkaline hydrolysis of the samples according to the procedures of Ravindran \& Bryden (1996).

The AIA contents of diet and digesta samples were measured after ashing the samples and treating the ash with boiling $4 \mathrm{M}-\mathrm{HCl}$ (Siriwan et al. 1993).

\section{Calculations}

The flow of each AA at the terminal ileum was calculated as $\mathrm{mg} / \mathrm{kg}$ ingested feed DM using the following formula
(Moughan et al. 1992; for the protein-free diet and EHC methods, this value was considered to be the estimate for endogenous flow):

$$
\begin{aligned}
& \text { AA flow (mg/kg DM intake) } \\
& =\mathrm{AA} \text { concentration in ileal digesta }(\mathrm{mg} / \mathrm{kg}) \\
& \times\left(\frac{\text { diet } \operatorname{AIA}(\mathrm{mg} / \mathrm{kg})}{\text { ileal AIA }(\mathrm{mg} / \mathrm{kg})}\right) \text {. }
\end{aligned}
$$

For the guanidination method, the contribution of endogenous AA to AA flow at the terminal ileum was first calculated from changes in the homoarginine:each individual acid ratios in guanidinated casein from those measured in ileal digesta, as shown (Siriwan et al. 1994; Caine et al. 1998):

contribution of endogenous secretions to amino acids at the distal ileum(\%)

$$
=\left(\frac{1-\mathrm{HAA}_{i}}{\mathrm{HAA}_{d}}\right) \times 100
$$

where $\mathrm{HAA}_{\mathrm{i}}$ is the homoarginine:AA ratio in ileal digesta and $\mathrm{HAA}_{\mathrm{d}}$ is the homoarginine:AA ratio in the diet.

The flow of endogenous AA, expressed as $\mathrm{mg} / \mathrm{kg}$ DM intake, was then calculated by multiplying the flow of each AA (equation 1) by the contribution of each AA to endogenous secretions (equation 2):

endogenous AA flow $(\mathrm{mg} / \mathrm{kg}$ DM intake $)=$ AA flow $\times$ contribution of endogenous secretions to AA at the distal ileum $(\%)$.

The AA composition of endogenous protein determined by each method was calculated by expressing each AA as a percentage of endogenous crude protein $(\mathrm{N} \times 6 \cdot 25)$.

\section{Statistical analysis}

The data were statistically analysed using the General Linear Models procedure (Minitab version 11, 1996; State College, PA, USA). When the $F$ value was significant $(P<0.05)$, mean values were separated using the least significant difference test.

\section{Results}

The birds were healthy throughout the experiment. There was no evidence of any intestinal or gross organ abnormalities when birds were killed at the conclusion of the study. The protein-free and $\mathrm{GuC}$ diets were less readily consumed than the EHC diet. Average daily feed intake of birds fed the protein-free, $\mathrm{EHC}$ and $\mathrm{GuC}$ diets during the $4 \mathrm{~d}$ feeding period were 76, 102 and 82 (pooled SEM 5.3) g/bird respectively. The corresponding values for daily weight gains were $-8,46$ and 12 (pooled SEM 2.2) g per bird respectively. The determined AA compositions of the three experimental diets are shown in Table 2.

The influence of the three methods on the ileal endogenous flows of $\mathrm{N}$ and AA, expressed as $\mathrm{mg} / \mathrm{kg} \mathrm{DM}$ intake, is shown in Table 3. For all AA, endogenous flows were influenced by the method of determination. The endogenous flows of $\mathrm{N}$ and $\mathrm{AA}$ in birds given the $\mathrm{EHC}$ and $\mathrm{GuC}$ diets were significantly $(P<0.05$ to $P<0.001)$ greater 
Table 2. Determined protein and amino acid composition $(\mathrm{g} / \mathrm{kg}$, airdry basis) of the protein-free diet and diets containing enzyme hydrolysed casein $(\mathrm{EHC})$ and guanidinated casein $(\mathrm{GuC})^{\star}$

\begin{tabular}{lcrr}
\hline & Protein-free diet & EHC diet & GuC diet \\
\hline Crude protein $(\mathrm{N} \times 6.25)$ & 3.43 & 189.60 & 194.40 \\
Asp & 0.19 & 17.22 & 13.33 \\
Thr & 0.06 & 10.03 & 8.92 \\
Ser & 0.09 & 11.03 & 11.28 \\
Glu & 0.34 & 44.25 & 45.53 \\
Gly & 0.11 & 3.86 & 4.03 \\
Ala & 0.09 & 6.75 & 6.76 \\
Val & 0.10 & 10.26 & 11.19 \\
Ile & 0.10 & 10.03 & 11.00 \\
Leu & 0.11 & 16.11 & 16.42 \\
Tyr & 0.08 & 6.01 & 8.22 \\
Phe & 0.05 & 10.21 & 11.29 \\
His & 0.02 & 5.59 & 6.87 \\
Lys & 0.11 & 15.42 & 0.26 \\
Arg & 0.09 & 8.16 & 8.38 \\
Met & 0.06 & 5.24 & 5.03 \\
Cystine & 0.08 & 0.88 & 1.06 \\
Trp & nd & 1.98 & 2.23 \\
Homoarginine & - & - & 26.04 \\
\hline
\end{tabular}

nd, not detected.

${ }^{*}$ For details of the composition of the diets, see Table 1.

Table 3. lleal endogenous flows ( $\mathrm{mg} / \mathrm{kg} \mathrm{DM}$ intake) in 5-week-old broiler chickens determined by the protein-free diet, enzyme hydrolysed casein (EHC) and guanidinated casein (GuC) methods*

(Mean values for three replicates of five birds each with their pooled standard errors)

\begin{tabular}{lcrrr}
\hline & $\begin{array}{c}\text { Protein-free } \\
\text { diet }\end{array}$ & EHC & GuC & \multicolumn{1}{c}{ SEM } \\
\hline $\mathrm{N}$ & $1172^{\mathrm{b}}$ & $3080^{\mathrm{a}}$ & $3143^{\mathrm{a}}$ & $105 \cdot 1$ \\
Crude protein & $7329^{\mathrm{b}}$ & $19254^{\mathrm{a}}$ & $19647^{\mathrm{a}}$ & $657 \cdot 1$ \\
$\quad(\mathrm{~N} \times 6 \cdot 25)$ & & & & \\
Asp & $607^{\mathrm{b}}$ & $1425^{\mathrm{a}}$ & $1589^{\mathrm{a}}$ & $116 \cdot 3$ \\
Thr & $512^{\mathrm{b}}$ & $1089^{\mathrm{a}}$ & $1443^{\mathrm{a}}$ & $137 \cdot 1$ \\
Ser & $424^{\mathrm{b}}$ & $1016^{\mathrm{a}}$ & $1031^{\mathrm{a}}$ & $42 \cdot 5$ \\
Glu & $721^{\mathrm{b}}$ & $3868^{\mathrm{a}}$ & $3559^{\mathrm{a}}$ & $303 \cdot 9$ \\
Gly & $508^{\mathrm{b}}$ & $1431^{\mathrm{a}}$ & $1422^{\mathrm{a}}$ & $68 \cdot 5$ \\
Ala & $293^{\mathrm{b}}$ & $691^{\mathrm{a}}$ & $735^{\mathrm{a}}$ & $65 \cdot 6$ \\
Val & $417^{\mathrm{b}}$ & $945^{\mathrm{a}}$ & $1062^{\mathrm{a}}$ & $82 \cdot 2$ \\
Ile & $287^{\mathrm{a}}$ & $880^{\mathrm{a}}$ & $1062^{\mathrm{a}}$ & $71 \cdot 8$ \\
Leu & $439^{\mathrm{b}}$ & $999^{\mathrm{a}}$ & $1022^{\mathrm{a}}$ & $65 \cdot 0$ \\
Tyr & $253^{\mathrm{b}}$ & $611^{\mathrm{a}}$ & $666^{\mathrm{a}}$ & $45 \cdot 9$ \\
Phe & $287^{\mathrm{b}}$ & $733^{\mathrm{a}}$ & $762^{\mathrm{a}}$ & $66 \cdot 7$ \\
His & $158^{\mathrm{b}}$ & $441^{\mathrm{a}}$ & $427^{\mathrm{a}}$ & $39 \cdot 4$ \\
Lys & $209^{\mathrm{b}}$ & $1048^{\mathrm{a}}$ & $783^{\mathrm{a}}$ & $104 \cdot 3$ \\
Arg & $280^{\mathrm{c}}$ & $536^{\mathrm{b}}$ & $783^{\mathrm{a}}$ & $51 \cdot 6$ \\
Met & $101^{\mathrm{b}}$ & $249^{\mathrm{a}}$ & $241^{\mathrm{a}}$ & $27 \cdot 9$ \\
Cystine & $226^{\mathrm{b}}$ & $330^{\mathrm{a}}$ & $286^{\mathrm{a}}$ & $23 \cdot 1$ \\
Trp & $95^{\mathrm{b}}$ & $200^{\mathrm{a}}$ & $196^{\mathrm{a}}$ & $22 \cdot 0$ \\
Total amino & $5817^{\mathrm{b}}$ & $16491^{\mathrm{a}}$ & $17077^{\mathrm{a}}$ & $444 \cdot 6$ \\
acids & & & & \\
Amino acid-N & $849^{\mathrm{b}}$ & $2419^{\mathrm{a}}$ & $2517^{\mathrm{a}}$ & $49 \cdot 6$ \\
Amino acid-N & $72 \cdot 4$ & $78 \cdot 8$ & $80 \cdot 0$ & $2 \cdot 84$ \\
(\% total N) & & & & \\
\hline
\end{tabular}

${ }_{\mathrm{a}, \mathrm{b}}$ Mean values within a row with unlike superscript letters were significantly different $(P<0.05)$.

* For details of compositions of diets, see Table 1; for details of procedures, see pp. 218-219.

than those given the protein-free diet. Flows of individual $\mathrm{AA}$ in birds fed the EHC or $\mathrm{GuC}$ diets ranged from 1.3 (cystine) to 5.4 (glutamic acid) times higher than those fed the protein-free diet. The losses of $\mathrm{N}$ and total AA from $\mathrm{GuC}$ and $\mathrm{EHC}$ methods were almost 3-fold greater $(P<0.05)$ than those determined by the protein-free diet method. The endogenous flows of $\mathrm{N}$ and most AA obtained using the $\mathrm{GuC}$ and EHC methods were similar $(P>0.05)$. The only exception was arginine flow, which was lower $(P<0.05)$ in the EHC method. The endogenous lysine flow determined by the EHC method was $34 \%$ greater than that determined by the $\mathrm{GuC}$ method, but the difference was not significant $(P>0 \cdot 05)$.

The influence of methodology on the AA composition of endogenous protein, expressed as $\mathrm{g} / \mathrm{kg}$ crude protein $(\mathrm{N} \times 6 \cdot 25)$, is summarised in Table 4 . The method of determination had no effect on the AA composition of endogenous protein, except for threonine, glutamic acid, lysine, arginine and cystine. The concentrations of threonine and arginine were lower $(P<0 \cdot 05)$ and that of lysine was higher $(P<0.05)$ with the EHC method compared with the other two methods. The concentration of glutamic acid was greater $(P<0.05)$ and that of cystine was lower $(P<0.05)$ in the EHC and GuC methods compared with the protein-free diet method.

\section{Discussion}

Published data on endogenous AA flows at the terminal ileum of growing broiler chickens are limited. Ileal endogenous AA flows in birds fed the protein-free diet were similar to those determined for growing broiler chickens using the protein-free diet method (Siriwan et al. 1994; Cremers et al. 2001). To our knowledge, no comparative data is available on ileal endogenous AA losses in chickens, determined with the three methods evaluated in the current study, namely, the protein-free diet, EHC and $\mathrm{GuC}$ methods. Endogenous losses of AA determined

Table 4. Composition of ileal endogenous amino acid flow $(\mathrm{g} / \mathrm{kg}$ crude protein $(\mathrm{N} \times 6.25))$ in 5 -week-old broiler chickens as influenced by the protein-free diet, enzyme hydrolysed casein (EHC) and guanidinated casein (GuC) methods*

(Mean values for three replicates of five birds each with their pooled standard errors)

\begin{tabular}{|c|c|c|c|c|}
\hline & Protein-free diet & $\mathrm{EHC}$ & GuC & SEM \\
\hline Asp & $82 \cdot 8$ & $74 \cdot 2$ & $80 \cdot 8$ & 3.9 \\
\hline Thr & $69 \cdot 8^{a}$ & $57 \cdot 0^{\mathrm{b}}$ & $73 \cdot 4^{a}$ & 3.4 \\
\hline Ser & $57 \cdot 8$ & 52.9 & $52 \cdot 5$ & $2 \cdot 3$ \\
\hline Glu & $98 \cdot 3^{b}$ & $201 \cdot 2^{\mathrm{a}}$ & $181 \cdot 2^{a}$ & $4 \cdot 1$ \\
\hline Gly & $69 \cdot 4$ & 74.5 & $72 \cdot 3$ & $2 \cdot 6$ \\
\hline Ala & $40 \cdot 0$ & $36 \cdot 0$ & $37 \cdot 4$ & 1.6 \\
\hline Val & $57 \cdot 0$ & $49 \cdot 2$ & $54 \cdot 1$ & $2 \cdot 8$ \\
\hline lle & $39 \cdot 2$ & $45 \cdot 8$ & $54 \cdot 1$ & $4 \cdot 2$ \\
\hline Leu & 59.9 & $52 \cdot 1$ & $52 \cdot 0$ & $3 \cdot 0$ \\
\hline Tyr & 34.5 & $31 \cdot 8$ & 33.8 & 1.8 \\
\hline Phe & $39 \cdot 2$ & $38 \cdot 3$ & 38.8 & 1.9 \\
\hline His & $21 \cdot 6$ & $2 \cdot 29$ & $22 \cdot 3$ & $1 \cdot 2$ \\
\hline Lys & $28 \cdot 5^{\mathrm{b}}$ & $54 \cdot 8^{a}$ & $40 \cdot 0^{\mathrm{b}}$ & $4 \cdot 2$ \\
\hline Arg & $38 \cdot 1^{a}$ & $28 \cdot 0^{\mathrm{b}}$ & $39 \cdot 9^{a}$ & $2 \cdot 7$ \\
\hline Met & $13 \cdot 8$ & 12.9 & $12 \cdot 3$ & 1.6 \\
\hline Cystine & $30 \cdot 8^{a}$ & $17 \cdot 3^{b}$ & $14 \cdot 6^{\mathrm{b}}$ & 1.5 \\
\hline Trp & $13 \cdot 0$ & $10 \cdot 5$ & $10 \cdot 0$ & $1 \cdot 1$ \\
\hline
\end{tabular}

a,b Mean values within a row with unlike superscript letters were significantly different $(P<0.05)$.

* For details of compositions of diets, see Table 1; for details of procedures, see pp. 218-219. 
under normal physiological conditions using either peptide or protein alimentation were similar, and the values determined by these two methods were substantially greater than those determined with the traditional protein-free diet method. The latter findings are consistent with those of Siriwan et al. (1994), who observed 2-fold greater values for ileal endogenous AA losses in chickens using the $\mathrm{GuC}$ method when compared with the protein-free diet. Higher ileal endogenous AA flows when using the EHC method compared with the protein-free diet have been observed with rats (Darragh et al. 1990; Donkoh et al. 1995) and pigs (Butts et al. 1993). In the only study comparing EHC and a protein-free diet in chickens, Cremers et al. (2001) found that the endogenous AA data from the protein-free diet method were similar to those determined using the EHC method. The EHC diet used in the study of Cremers et al. (2001) contained $100 \mathrm{~g}$ crude protein $(\mathrm{N} \times 6.25) / \mathrm{kg}$ compared with $180 \mathrm{~g}$ crude protein $(\mathrm{N} \times 6.25) / \mathrm{kg}$ in the present study, which may explain the observed discrepancy. Dietary peptide concentration has been shown to influence endogenous AA flows in growing pigs, with endogenous flows increasing with increasing dietary inclusion levels of EHC (Hodgkinson et al. 2000). The endogenous AA flows in broilers determined after feeding diets containing $100 \mathrm{~g} \mathrm{EHC/kg}$ by Rutherfurd et al. (2002) were also closer to the values from the protein-free diet method in the present study. The source of EHC may be another factor that may contribute to variable results, since different proteolytic enzyme cocktails may produce peptide hydrolysates of different types and sizes from the same starting source. The source of EHC or its molecular mass profile was not indicated in the reports of Cremers et al. (2001) and Rutherfurd et al. (2002). The possible relationship between peptide size and gut endogenous AA secretions warrants further investigation.

The endogenous flow of arginine determined by the EHC method was lower than that determined by the $\mathrm{GuC}$ method. Interestingly, the lysine flow determined by the EHC method was greater, although the differences were not statistically significant. The use of greater number of replicates may have increased the probability of statistical significance. Interestingly, Hodgkinson et al. (1999) also reported that the endogenous lysine flow in pigs determined by the $\mathrm{GuC}$ method was lower than that determined by the EHC method. The significance of and the reasons for these findings are unclear. The $\mathrm{GuC}$ diet contained extremely low levels of lysine compared with the EHC diet $(0.26 v .19 .4 \mathrm{~g} / \mathrm{kg}$ in the current study), but it is unlikely that this difference would have contributed to this observation. By definition, when a very low level of dietary lysine is offered as in the feeding of $\mathrm{GuC}$ diet, almost all ileal lysine determined must be of endogenous origin (Moughan et al. 1998). This is a valid assumption and then it follows that the EHC method overestimates ileal lysine flow rather than the $\mathrm{GuC}$ method underestimating the lysine flow. Since lysine concentration is not particularly high in mucoproteins, which dominate endogenous flow, it may be speculated that some of the increase in lysine flow in the EHC method may have been caused from undigested lysine in the EHC. These data raise questions about the validity of the assumption in the EHC method that the precipitate from the centrifugation step and the retentate from the ultrafiltration step $(>10 \mathrm{kDa})$ represent the endogenous component of the digesta and not undigested dietary AA. The AA profile of the endogenous protein flow (Table 4), where there is a large increase in lysine in the EHC compared with the protein-free diet, lends support to this possibility. The higher than anticipated endogenous lysine level with EHC in the present study, however, is in contrast to results reported with pigs (Butts et al. 1991; Moughan et al. 1992; Leterme et al. 1996). Future evaluation with poultry is clearly needed and, until further data are available, the endogenous lysine results must be considered with caution.

The flow of endogenous protein at the terminal ileum represents a balance between secretion and re-absorption. Both these aspects can be influenced by protein and peptide alimentation (Nyachoti et al. 1997; Moughan et al. 1998). The increased flow of endogenous AA in the presence of protein and peptides, therefore, may be attributed to an increase in digestive enzyme secretions, a decreased efficiency of re-absorption or both. Published data supporting these hypotheses, however, is limited. Ozimek et al. (1985) observed that a reduction in dietary protein content decreased pancreatic secretions of trypsin, chymotrypsin, amylase and lipase as well as total protein secretion. It has been suggested that the rate of degradation of digestive enzymes may be lower in the presence of protein (Snook \& Meyer, 1964), with dietary proteins protecting digestive enzymes from hydrolysis by being preferentially used as substrates.

In agreement with previous data from pigs (Rademacher et al. 1999; Pedersen \& Boisen, 2002), glutamic acid, aspartic acid, threonine and glycine dominate the AA profile of endogenous protein in the ileal digesta of growing chickens. The concentrations of methionine, histidine and cystine were lower compared with other AA. The endogenous protein reaching the distal ileum is reported to consist primarily of biliary secretions and mucin glycoproteins, because these components are largely resistant to proteolysis (Moughan \& Schuttert, 1991). Mucin glycoprotein is rich in proline, glutamic acid, aspartic acid, threonine and serine (Lien et al. 1997), and glycine accounts for more than $90 \%$ of the AA content of bile (Souffrant, 1991). It has been also suggested that glycine, threonine, serine, aspartic acid and glutamic acid in endogenous proteins may be absorbed more slowly from the gut lumen compared with other AA (Taverner et al. 1981). As a result, endogenous protein is reported to have a high content of these AA.

Since mucins represent a major source of endogenous losses, one might anticipate that threonine losses would be higher, but this was not the case. The fact that glutamic acid concentrations are considerably higher in EHC and GuC methods points to two possibilities. First, as glutamine is converted to glutamate upon hydrolysis of proteins, the extraordinarily high glutamate levels probably represent the sum of glutamate plus glutamine. Second, casein is high in both glutamate and glutamine, and lysine represents $85 \mathrm{~g} / \mathrm{kg}$ casein. Thus, it may be speculated that the higher losses of these AA with $\mathrm{EHC}$ and $\mathrm{GuC}$ 
methods reflect, in part, less than $100 \%$ digestion of the $\mathrm{EHC}$ and $\mathrm{GuC}$.

The concentration of glutamic acid in endogenous protein was greater and that of cystine was lower in the $\mathrm{EHC}$ and $\mathrm{GuC}$ methods compared with the protein-free diet method. It is difficult to provide precise explanations for the observed differences. It is known, however, that individual sources of endogenous protein have different AA composition (Souffrant, 1991; Lien et al. 1997) and this could have influenced the AA profile of endogenous protein.

Proline concentrations were not measured in the AA analysis system used in the present study. It has been shown that proline can make up a significant portion of ileal endogenous flow in pigs fed protein-free diets (de Lange et al. 1989) and this finding was suggested as an indication of disturbances in protein metabolism. Unusually, a high ileal flow of proline has not been reported when animals are fed diets containing protein and peptides (Jansman et al. 2002).

Feed intake of birds given the protein-free diet was similar to those given the $\mathrm{GuC}$ diet, but the latter method yielded significantly higher estimates of endogenous AA flow. On the other hand, feed intake of birds given the $\mathrm{GuC}$ diet was significantly lower than that when given the EHC diet, but the estimates of endogenous AA flow were similar. These observations appear to suggest that the endogenous AA flows, measured in relation to DM intake, may not be related to feed intake; further studies are needed to test this hypothesis. Published data on the effects of feed intake on endogenous AA flows in pigs have been contradictory (Butts et al. 1993; Hess \& Seve, 1999; James et al. 2002). Studies by Angkanaporn et al. (1997) have shown that the low feed intake in birds fed the $\mathrm{GuC}$ diet can be attributed to a direct effect of lysine deficiency and/or homoarginine per se on feed intake regulation.

In summary, the present results demonstrate that the protein-free diet method is intrinsically unsound, because the absence of protein and a negative $\mathrm{N}$ balance, as indicated by the weight loss in broilers receiving this diet, alter endogenous secretions and causes gross underestimation of ileal endogenous flows. The greater flows of ileal $\mathrm{N}$ and $\mathrm{AA}$ in the presence of protein and peptides, above those determined following feeding of a protein-free diet, support the original thesis that the presence of dietary peptides or protein in the gut markedly enhances the endogenous flows of AA. It would therefore appear that the use of $\mathrm{EHC}$ and $\mathrm{GuC}$ methods represent an improvement over the traditional protein-free diet method for the measurement of endogenous protein flow. It is noteworthy, however, that several assumptions have to be made when these methods are employed. The assumptions and possible limitations of these two methods have been detailed elsewhere (Nyochoti et al. 1997; Ravindran \& Bryden, 1999). Most of the assumptions appear to be reasonable (Bryden et al. 1996; Moughan et al. 1998) and the major advantage of these two methodologies is that the endogenous losses in animals can be measured under normal physiological conditions.

From a practical point of view, it is important to measure with accuracy the amount of endogenous protein in ileal digesta to improve the precision of true AA digestibility calculations and feed formulations. However, the applicability of estimates generated with $\mathrm{EHC}$ and $\mathrm{GuC}$ methods to correct apparent AA digestibility of low-protein feedstuffs, such as cereal grains and grain legumes, is questionable. Application of these endogenous AA estimates, determined at dietary protein levels of $190 \mathrm{~g} / \mathrm{kg}$, for digestibility corrections will result in only small increases in the true AA digestibility of high-protein feedstuffs, but can cause marked differences between apparent and true values in low-protein feedstuffs. Recent evidence suggests that increasing the peptide concentrations may have a dosedependent effect on ileal endogenous AA flows (Hodgkinson et al. 2000). If this is established, then it follows that the use of one set of values for endogenous correction of feedstuffs with varying protein concentrations is not valid. It will be necessary in future evaluations to measure the endogenous flows in poultry given a range of dietary levels of peptides or protein and then to use different endogenous AA corrections depending on the protein content of the feedstuff.

\section{Acknowledgements}

This study was funded by the Australian Chicken Meat Committee of the Rural Industries Research and Development Corporation, Canberra and the Poultry Research Foundation, The University of Sydney, Camden.

\section{References}

Angkanaporn K, Choct M, Bryden WL, Annison EF \& Annison G (1994) Effect of wheat pentosans on endogenous amino acid losses in chickens. J Sci Food Agric 66, 399-404.

Angkanaporn K, Ravindran V, Mollah Y \& Bryden WL (1997) Homoarginine influences voluntary feed intake, tissue basic amino acid concentrations and arginase activity in chickens. $J$ Nutr 127, 1128-1136.

Bryden WL, Angkanaporn K, Ravindran V, Imbeah M \& Annison EF (1996) Use of homoarginine technique to determine endogenous amino acid losses in poultry and pigs. In Protein Metabolism and Nutrition, European Association of Animal Production Publication no. 81, pp. 319-323 [AF Nunes, AV Portugal, JP Costa and JR Ribeiro, editors]. Vale de Saltoverm: Estacao Zootecnica Nacional.

Butts CA, Moughan PJ \& Smith WC (1991) Endogenous amino acid flow at the terminal ileum of the rat determined under conditions of peptide alimentation. J Sci Food Agric 55, 175-187.

Butts CA, Moughan PJ, Smith WC, Reynolds GW \& Garrick DJ (1993) The effect of food dry matter intake on endogenous endogenous ileal amino acid excretion determined under peptide alimentation in the $50 \mathrm{~kg}$ liveweight pig. J Sci Food Agric 62, 235-243.

Caine WR, Sauer WC, Verstegen WA, Tamminga S, Li S \& Schulze H (1998) Guanidinated protein test meals with higher concentration of soybean trypsin inhibitors increase ileal recoveries of endogenous amino acids in pigs. $J$ Nutr 128, 598-605.

Cremers S, Pallauf J, Hohler D, Lemme A \& Pack M (2001) Endogenous amino acid flow at the distal ileum of growing broiler chickens fed different diets. In Proceedings of the 13th European Symposium on Poultry Nutrition, pp. 254-255 Blankenburg: World's Poultry Science Association. 
Darragh AJ, Moughan PJ \& Smith WC (1990) The effect of amino acid and peptide alimentation on the determination of endogenous amino acid flow at the terminal ileum of the rat. J Sci Food Agric 51, 47-56.

de Lange CFM, Sauer WC, Mosenthin R \& Souffrant WB (1989) The effect of feeding different protein-free diets on the recovery and amino acid composition of endogenous protein collected from the distal ileum and feces of pigs. J Anim Sci 67, 746-754.

Donkoh A, Moughan PJ \& Morel PCH (1995) Comparison of methods to determine the endogenous amino acid flow at the terminal ileum of the growing rat. J Sci Food Agric 67, 359-366.

Hagemeister H \& Erbersdobler H (1985) Chemical labelling of dietary protein by transformation of lysine to homoarginine: a new technique to follow intestinal digestion and absorption. Proc Nutr Soc 44, 133A.

Hess V \& Seve B (1999) Effects of body weight and feed intake level on basal ileal endogenous losses in growing pigs. J Anim Sci 77, 3281-3288.

Hodgkinson SM, Moughan PJ, Reynolds GW \& James KAC (2000) The effect of dietary peptide concentration on endogenous ileal amino acid loss in the growing pig. Br J Nutr 83, 421-430.

Hodgkinson SM, Souffrant WB \& Moughan PJ (1999) Comparison of three methods for determining endogenous ileal protein flow in the growing pig. In Manipulating Pig Production VII, p. 270 [PD Cranwell, editor]. Canberra: Australian Pig Science Association.

Imbeah M, Angkanaporn K, Ravindran V \& Bryden WL (1996) Investigations on the guanidination of lysine in proteins. $J$ Sci Food Agric 72, 213-218.

James KAC, Butts CA, Koolaard JP, Donaldson HE, Scott MF \& Moughan PJ (2002) The effect of food dry matter intake on the flow of amino acids at the terminal ileum for rats fed an enzyme-hydrolysed casein-based diet. J Sci Food Agric 82, 1128-1135.

Jansman AJM, Smink W, van Leeuwen P \& Rademacher M (2002) Evaluation through literature data of the amount and amino acid composition of basal endogenous crude protein at the terminal ileum of pigs. Anim Feed Sci Technol 98, 49-60.

Leterme P, Monmart T, Thewis A \& Morandi P (1996) Effect of oral and parenteral $\mathrm{N}$ nutrition vs $\mathrm{N}$-free nutrition on the endogenous amino acid flow at the ileum of the pig. $J$ Sci Food Agric 71, 265-271.

Lien KA, Sauer WA \& Fenton M (1997) Mucin output in ileal digesta of pigs fed a protein-free diet. J Anim Sci 72, $1737-1743$.

Moore S (1963) On the determination of cystine as cysteic acid. $J$ Biol Chem 238, 235-237.

Moughan PJ, Darragh AJ, Smith WC \& Butts CA (1990) Perchloric and trichloraacetic acids as precipitants of protein in endogenous ileal digesta from the rat. J Sci Food Agric 52, $13-21$.

Moughan PJ \& Schuttert G (1991) Composition of nitrogen-containing fractions in digesta from the distal ileum of pigs fed a protein-free diet. J Nutr 121, 1570-1574.
Moughan PJ, Schuttert G \& Leenaars M (1992) Endogenous amino acid flow in the stomach and small intestine of the young growing pig. J Sci Food Agric 60, 437-442.

Moughan PJ, Souffrant WB \& Hodgkinson SM (1998) Physiological approaches to determining gut endogenous amino acid flows in the mammal. Arch Anim Nutr 51, 237-252.

Nyachoti CM, de Lange CFM, McBride BW \& Schulze H (1997) Significance of endogenous gut protein losses in the nutrition of growing pigs. Can J Anim Sci 77, 149-163.

Ozimek L, Sauer WC \& Ozimek G (1985) Effect of Diet on the Qualitative and Quantitative Adaptation of Exocrine Pancreas Secretions. Feeders Day Report, Vol. 63, pp. 16-20. University of Alberta: Department of Animal Science.

Pedersen C \& Boisen S (2002) Establishment of tabulated values for standardized ileal digestibility of crude protein and essential amino acids in common feedstuffs for pigs. Acta Agric Scand A 52, 121-140.

Rademacher M, Sauer WC \& Jansman AJM (1999) Standardised Ileal Digestibility of Amino Acids in Pigs. Hanua: Feed Additives Division, Degussa-Huls AG.

Ravindran G \& Bryden WL (1996) Determination of the tryptophan content of proteins by ion exchange chromatography. Proc Nutr Soc Aust 20, 105.

Ravindran V \& Bryden WL (1999) Amino acid availability in poultry - in vitro and in vivo measurements. Aust J Agric Res 50, 889-908.

Ravindran V, Imbeah M, Angkanaporn K \& Bryden WL (1996) Guanidination of lysine in cottonseed protein. J Agric Food Chem 44, 1812-1815.

Rutherfurd SM, Chung TK \& Moughan PJ (2002) The effect of microbial phytase on ileal phosphorus and amino acid digestibility in the broiler chicken. Br Poult Sci 44, 598-606.

Sibbald IR (1987) Estimation of bioavailable amino acids in feedstuffs for poultry and pigs: a review with emphasis on balance experiments. Can J Anim Sci 67, 221-230.

Siriwan P, Bryden WL \& Annison EF (1994) Use of guanidinated dietary protein to measure losses of endogenous amino acids in poultry. Br J Nutr 71, 515-529.

Siriwan P, Bryden WL, Mollah Y \& Annison EF (1993) Measurement of endogenous amino acid losses in poultry. Br Poult Sci 34, 939-949.

Snook JT \& Meyer JH (1964) Response of digestive enzymes to dietary protein. J Nutr 82, 409-414.

Souffrant WB (1991) Endogenous nitrogen losses during digestion in pigs. In Proceedings of the Vth International Symposium on Digestive Physiology in Pigs, pp. 147-166 [MWA Verstegen, J Huisman and LA den Hartog, editors]. Wageningen: PUDOC.

Sweeney RA (1989) Generic combustion method for determination of crude protein in feeds: Collaborative study. $J$ Assoc Off Anal Chem 72, 770-774.

Taverner MR, Hume ID \& Farrell DJ (1981) Availability to pigs of amino acids in cereal grains. 1. Endogenous levels of amino acids in ileal digesta and faeces of pigs given cereal diets. $B r J$ Nutr 46, 149-158. 